\title{
The Ambangulu Forest, West Usambara Mountains, Tanzania: a threatened Eastern Arc forest
}

Ambangulu Forest is one of the few remaining tracts of natural forest between 800 and $1200 \mathrm{~m}$ in the West Usambara Mountains of Tanzania. It may be the biologically richest area in the region but it is threatened by illegal felling of timber trees, wind damage, grazing and browsing livestock, and collection of fuel-wood and building poles. $A$ proposed project aims to protect the forest and benefit local people at the same time.

The Eastern Arc Mountains of Tanzania have received a considerable amount of attention from biologists because of their unique biota and high levels of endemism (Lovett and Wasser, 1993). This is particularly true of the Usambara Mountains, which are divided into separate east and west ranges, where significant tracts of relatively intact forest still remain (Figure 1). However, much of the

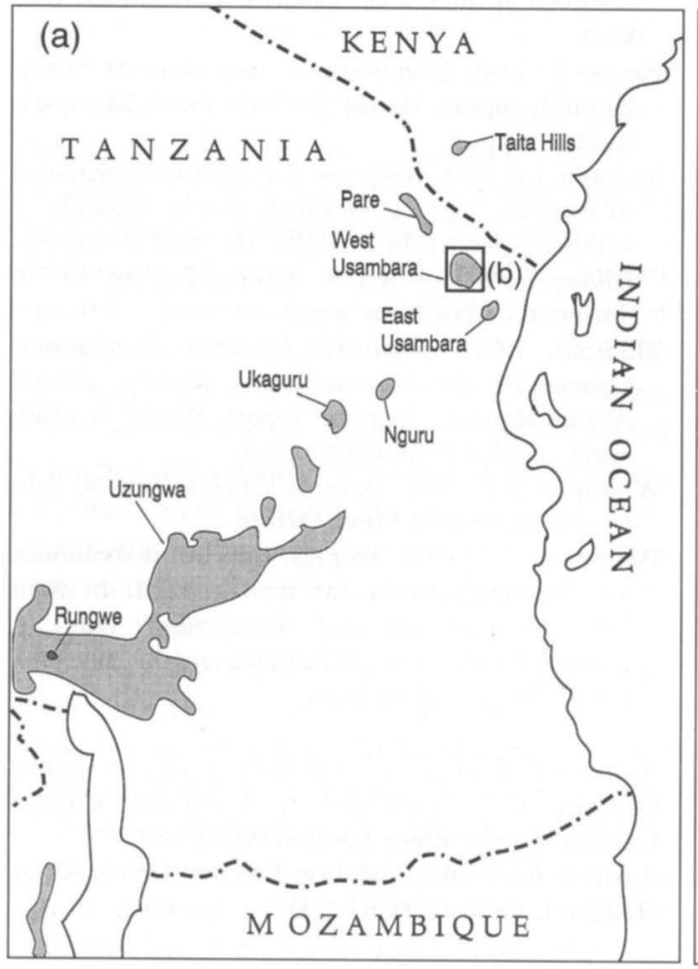

remaining forest is being threatened by human activities. Recent field-work and systematic studies have revealed high levels of forest endemic species: plants, 25 per cent (Iversen, 1991); linyphiid spiders, 86 per cent (Scharff, 1992); sphecid wasps, 37 per cent; diplopoda, 84 per cent; amphibia, 27 per cent; lizards, 64 per cent; snakes, 20 per cent; birds, 5 per cent (Rodgers and Homewood, 1982). Little has been published on small mammals (shrews, bats and rodents) of the Eastern Arc Mountains, and we are currently studying their ecology and biogeography in this area.

Most information on the biota of the Usambara Mountains comes from the Amani region of the East Usambaras, and subsequently this region has been the focus of considerable attention from the conservation community. This is largely due to Amani's

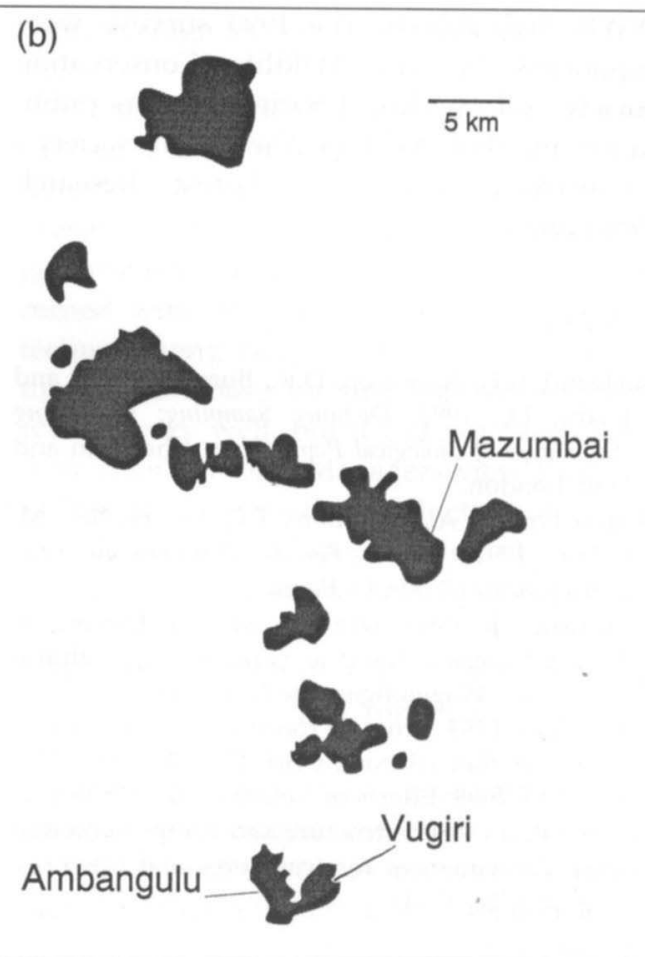

Figure 1. Map of Tanzania showing: (a) various Eastern Arc Mountain forests; and (b) various areas of forest in the West Usambara Mountains. 
Pit-sawing site involving windfelled trees in Ambangulu Forest in the West Usambara Mountains (S. M. Goodman).

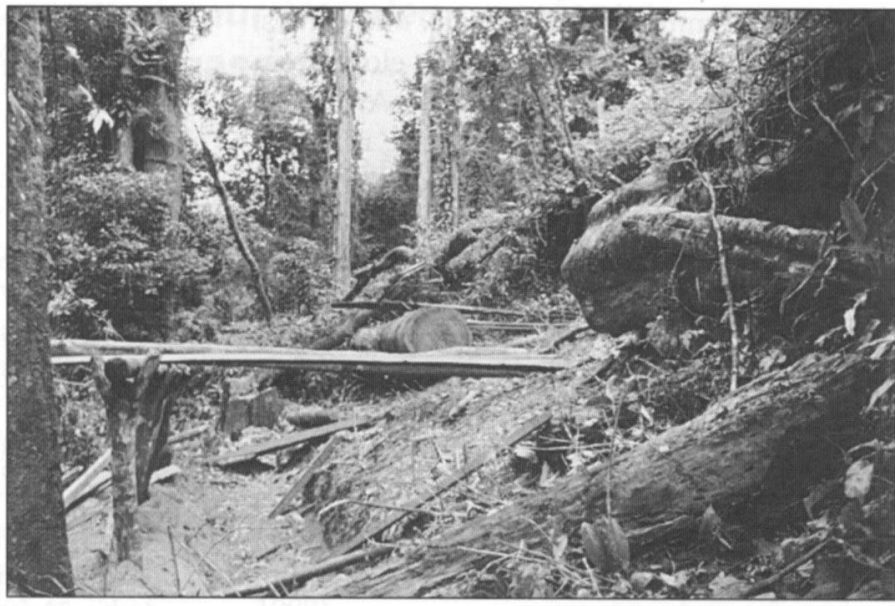

accessibility, local infrastructure, and the longterm presence of scientists associated with the former East African Agricultural Research Station. Even though other areas of the East and West Usambaras are biologically important and perhaps equally diverse, they have received little attention.

The East and West Usambaras share many faunistic and floristic elements (Rodgers and Homewood, 1982; Stuart, 1983; Iversen, 1991). However, information on the biota of the West Usambaras is less extensive (Pitt-Schenkel, 1938; Redhead, 1981; Rodgers and Homewood, 1982; Iversen, 1991; Lovett, 1991a,b,c). Currently there are 14 government forest reserves, 10 local authority forest reserves and the Sokoine University of Agriculture reserve at Mazumbai in the West Usambaras (Iversen, 1991; Figure 1). All but one of these are above $1500 \mathrm{~m}$. The exception is the local authority forest reserve of Vugiri, which is only 40 ha (Lovett and Pócs, 1993) and which is the only reserve to protect intermediate-altitude forest in the West Usambaras.

Species diversity in the Usambara Mountains is not evenly distributed. On the basis of distribution data for birds (Stuart, 1983) and plants (Iversen, 1991), the biologically richest zone is between 800 and $1200 \mathrm{~m}$ (Newmark, 1993). We believe that mammal species diversity is also the highest in this same zone.

Several tracts of natural forest remain in the south-west corner of the West Usambaras, within the Ambangulu Tea Estate (a concession of the George Williamson tea company). These are remnants of a more extensive forest and are the largest remaining blocks below $1500 \mathrm{~m}$ in the West Usambaras. The largest single tract within the Korogwe District, approximately 890 ha and hereafter referred to as the Ambangulu Forest, is situated between 1100 and $1300 \mathrm{~m}$ (Figure 1). Given its size and altitude, the Ambangulu Forest may be the richest area biologically in the West Usambara Mountains. In addition, it is a catchment forest for the town of Korogwe and further destruction could have devastating results for Korogwe in terms of water supply and floods.

The Ambangulu Forest is currently under serious threat. Illegal felling of trees for timber is the primary pressure on the remaining natural forest. Past deforestation has created gaps in the forest canopy and has rendered much of the remaining forest vulnerable to high winds, as witnessed by a severe storm on 6 March 1990, which toppled a significant portion of large canopy trees on the upper ridges (Reid, 1991). The grazing of cattle and goats in forested areas is also a problem, as is the gathering of building-poles and fuel-wood by local residents. In the past the tea estate harvested portions of the original forest for drying tea. However, in recent years, many deforested areas have been replanted with Eucalyptus and Maesopsis and the tea estate is now self-sufficient in fuel-wood.

The Ambangulu Forest can be protected 
only if government and private authorities, along with local people, can develop a cooperative plan to manage the area. At the request of the Ambangulu Tea Estate management, a project concept paper to conserve the Ambangulu Forest was drafted and submitted to George Williamson Limited, Korogwe District authorities and an external donor for initial consideration. (This paper is available upon request from the first three authors of the present communication.) The principal objectives of this proposed project are to promote the conservation of the Ambangulu Forest and to reduce the dependency of people upon natural forest resources. It would involve the following parties: Ambangulu Tea Estate, Korogwe District authorities, local villages and external donors. The project would focus upon four major activities: forest protection, village extension, hardwood management and ecotourism. Adoption of this plan would assist greatly the conservation of this forest. Recently, the parties involved in this proposed project have voiced support and we are encouraged by the enthusiasm expressed.

\section{Acknowledgements}

We are grateful to George Williamson Limited for allowing us to work in the Ambangulu Forest with special thanks to Herbert Kingazi and Simon Mfikwa, Ambangulu Tea Estate, for their hospitality and assistance. We thank the Tanzania Commission for Science and Technology and the Serengeti Wildlife Research Institute for permission to conduct this research. Thanks to Jodi Sedlock for help with the map. This research was supported in part by the Chicago Zoological Society, the Field Museum of Natural History, the National Geographic Society, the Sophie Danforth Conservation Fund and World Wide Fund for Nature.

\section{References}

Iversen, S.T. 1991. The Usambara Mountains, NE Tanzania: phytogeography of the vascular plant flora. Acta Universitatis Upsaliensis, Symbolae Botanicae Upsalienses, 29, 3.

Lovett, J.C. 1991a. Notes on the Shume-Magamba Forest of the West Usambara Mountains, Tanzania. East African Natural History Society Bulletin, 21, 27-28.
Lovett, J.C. 1991b. Notes on the Baga Forest, West Usambara Mountains, Tanzania. East African Natural History Society Bulletin, 21, 28-29

Lovett, J.C. 1991c. Notes on the forest at Ambangulu and Kunga in the West Usambara Mountains. East African Natural History Socicty Bulletin, 21, 29-30.

Lovett, J.C. and Pócs, T. 1993. Assessment of the Condition of the Catchment Forest Reserves, a Botanical Appraisal. The Catchment Forestry Project, Dar es Salaam.

Lovett, J.C. and Wasser, S.M. (eds). 1993. Biogeography and Ecology of the Rain Forests of Eastern Africa. Cambridge University Press, Cambridge.

Newmark, W.D. 1993. The role and design of wildlife corridors with examples from Tanzania. Ambio, 22, 500-504.

Pitt-Schenkel, C.J.W. 1938. Some important communities of warm temperate rain forest at Magamba, West Usambara, Tanganyika Territory. Journal of Ecology, 26, 50-75.

Redhead, J.F. 1981. The Mazumbai Forest: an island of lower montane rain forest in the West Usambaras. African Journal of Ecology, 19, 195-199.

Reid, C.M. 1991. Storm damage and deforestation in the West Usambara Mountains, Tanzania: a study using GIS. BSc (Hons) thesis, Tropical Environmental Science, Aberdeen University.

Rodgers, W.A. and Homewood, K.M. 1982. Species richness and endemism in the Usambara mountain forests, Tanzania. Biological Journal of the Linnean Society, 18, 197-242.

Scharff, N. 1992. The linyphiid fauna of eastern Africa (Araneae: Linyphiidae) - distribution patterns, diversity and endemism. Biological Journal of the Linnean Society, 45, 117-154.

Stuart. S.N. 1983. Biogeographical and ecological aspects of forest bird communities in eastern Tanzania. PhD thesis, Cambridge University.

Steven M. Goodman and William T. Stanley, Department of Zoology, Field Museum of Natural History, Roosevelt Road at Lake Shore Drive, Chicago, IL 60605, USA

William D. Newmark, Department of Biology, 201 Biology Building, University of Utah, Salt Lake City, Utah 84112, USA

Kim M. Howell, Department of Zoology, University of Dar es Salaam, PO Box 35064 ,

Dar es Salaam, Tanzania 